\title{
A new Dicranophragma (Diptera: Limoniidae) from a hypogeous environment in Catalonia (Iberian Peninsula)
}

\author{
Jorge MEDEROS ${ }^{1, *}$, Sergi GAGO ${ }^{2}$, Neus BRAÑAS ${ }^{3}$, Floren FADRIQUE ${ }^{4}$, \\ Berta CABALLERO-LÓPEZ ${ }^{5}$ \& Glòria MASÓ ${ }^{6}$ \\ 1,2,3,5,6 Museu de Ciències Naturals de Barcelona, Castell dels Tres Dragons, Passeig Picasso s/n, \\ 08003 Barcelona, Catalonia, Spain. \\ ${ }^{4}$ Associació Catalana de Bioespeleologia, Carrer Moreres 3, 43890 L'Hospitalet de l'Infant, \\ Tarragona, Catalonia, Spain. \\ *Corresponding author: mederos@gmail.com \\ 2Email:sgagoc@gmail.com \\ 33Email: nbranasv@gmail.com \\ ${ }^{4}$ Email: ffadrique@hotmail.com \\ ${ }^{5}$ Email: bcaballerolo@bcn.cat \\ ${ }^{6}$ Email: gmaso@bcn.cat
}

${ }^{1}$ urn:lsid:zoobank.org:author:201DC8A7-C38A-41D6-A5B7-E2B47F04FE12
${ }^{2}$ urn:lsid:zoobank.org:author:E105925B-859D-40F7-81FC-3FDF1E62574F
${ }^{3}$ urn:Isid:zoobank.org:author:0FA71116-E621-4D6F-B1DA-2E11020EA9EE
${ }^{4}$ urn:Isid:zoobank.org:author:90C2A5C4-A7ED-4DCA-8207-4692B7B81078
${ }^{5}$ urn:Isid:zoobank.org:author:8A7582B8-D902-4F33-9D37-9812A2F48595
${ }^{6}$ urn:lsid:zoobank.org:author:1E997B7C-03ED-4584-9031-D96BC87CF0BD

\begin{abstract}
A new species of Limnophilinae (Diptera: Limoniidae), Dicranophragma (Brachylimnophila) relictum Mederos sp. nov., is described. This is the third species of this genus recorded from the Iberian Peninsula. This new species was discovered in a cave in the Sant Llorenç del Munt i Serra de l'Obac Natural Park, Barcelona Province (Catalonia) and it is the first record of a species of this genus from a hypogeous environment. The absence of suitable ecological conditions for the survival of this new species, particularly in the vicinity of the cave, suggests that this population of $D$. relictum Mederos sp. nov. is isolated. Dicranophragma relictum Mederos sp. nov. is characterized by the following features: a general grey-to-greenish-grey coloration on its thorax and a dark-grey abdomen; wings more than four times longer than wide; pale-brown-to-yellowish tinted wings, with brown veins and a wellmarked stigma; in the male genitalia the upper part of the aedeagus is acute when viewed laterally and is longer than the lower part. A key is provided for separating the three species of Dicranophragma known to be present in the Iberian Peninsula.
\end{abstract}

Keywords. Limnophilinae, Tipuloidea, craneflies, cave dweller, Palearctic.

Mederos J., Gago S., Brañas N., Fadrique F., Caballero-López B. \& Masó G. 2020. A new Dicranophragma (Diptera: Limoniidae) from a hypogeous environment in Catalonia (Iberian Peninsula). European Journal of Taxonomy 724: 109-121. https://doi.org/10.5852/ejt.2020.724.1163 


\section{Introduction}

The family Limoniidae Rondani, 1856 contains almost 10700 described species that are found across the whole globe except Antarctica (Oosterbroek 2020). The genus Dicranophragma Osten Sacken, 1860 includes 49 described species and subspecies, grouped into three subgenera: Brachylimnophila Alexander, 1966, Dicranophragma and Mixolimnomyia Savchenko, 1979. Species of this genus have been described from the Nearctic, Palearctic, Afrotropical and Oriental regions (Oosterbroek 2020), the latter region having the greatest number of recorded species. Before the European species were reviewed by Starý \& Reusch (2009), Brachylimnophila was treated as a subgenus of Neolimnomyia Séguy, 1937. From the Iberian Peninsula, two species of Dicranophragma (Brachylimnophila) have been recorded to date, both of which are widely distributed throughout the Western and Eastern Palearctic: Dicranophragma (Brachylimnophila) adjunctum (Walker, 1848), recorded from Andorra (Canillo) and Spain (Barcelona, Guipúzcoa and Teruel), and Dicranophragma (B.) nemorale (Meigen, 1818), reported from Andorra (Canillo), Portugal (Serra da Estrela) (Eiroa 2002) and more recently from Spain (Jaén) (Hancock 2020; Hancock \& Hewitt 2020).

In 2019, a team from the Arthropod Department of the Barcelona Natural Sciences Museum (Museu de Ciències Naturals de Barcelona, MCNB) began a series of visits to Avenc del Daví, a cave in the Sant Llorenç del Munt i l'Obac Natural Park that had been selected as part of a study of two hypogean invertebrates, an isopod crustacean, Stenasellus virei Dollfus, 1897, and a leiodid coleopteran, Troglocharinus kiesenwetteri sanllorensi (Zariquiey, 1924), that are endemic to the area and enjoy a certain degree of protection. During the study, several specimens of a new species of Dicranophragma were observed and captured in Avenc del Daví. This cave is well studied since it houses a hibernation colony of the bat Miniopterus schreibersii (Kuhl, 1817) and so is regularly monitored (Serra-Cobo et al. 1998; Colombi et al. 2019). To protect M. schreibersii, access to this cave has been controlled since 1994 from November to the end of May.

\section{Material and methods}

This work focuses on the results obtained from the explorations of the Avenc del Daví (932 m a.s.l.) (Fig. 1), a deep cavity in NE-facing Eocene montane conglomerates in the Sant Llorenç del Munt $\mathrm{i}$ l'Obac Natural Park. This massif is part of an N-S diaclase, deeply degraded by decalcification and with a vertical development of up to -65 meters. The Sant Llorenç and l'Obac massif is predominantly calcareous but with some intercalations of siliceous rocks (DIBA 2020). The characteristic vegetation of the natural park is evergreen oak forest (Quercus ilex L.), which at lower altitudes includes typical Mediterranean shrubs such as Erica sp. and Arbutus unedo L. However, the area where the Avenc del Daví is located, above $800 \mathrm{~m}$ a.s.1., enjoys a relatively humid climate that allows forests to be enriched with species from more humid regions such as Sorbus aria (L.) Crantz, Buxus sempervirens L. and Quercus pubescens Willd. The entrance to the cave system itself is surrounded by a vegetation associated with Mediterranean oak forests. Access is through two wide entrances that permit abundant vegetable and animal organic material to fall into its interior. At $-40 \mathrm{~m}$, there is a chamber (about $50 \times 9$ $\mathrm{m})$ where all the fallen material accumulates.

Although the description of this new species is based on dry-mounted specimens, part of the type material were preserved in $70 \%$ ethanol. Specimens were examined with a Motic SMZ-168 Zoom stereo microscope and a Kyowa Unilux-12 83-483D. Images were taken by multi-stack with iPhone XR and subsequently processed with Helicon Focus 7. Measurements were made with an ocular reticule. When necessary, the male genitalia were macerated in a $4 \% \mathrm{KOH}$ solution and finally preserved in microvials with $70 \%$ alcohol, together with the respective specimens. We have adopted the classification according to Starý (1992), also used by the Catalogue of the Craneflies of the World (CCW) (Oosterbroek 2020), that includes Dicranophragma within the Limnophilinae Bigot, 1864, family Limoniidae. The 
morphological terminology mainly follows that of Gelhaus (2009) and Cumming \& Wood (2009), but also Starý \& Reusch (2009) for male terminalia.

\section{Depositories}

MCNB = Barcelona Natural Sciences Museum, Barcelona, Spain

MNHN = Muséum national d'histoire naturelle, Paris, France

RBINS $=$ Royal Belgian Institute of Natural Sciences, Brussels, Belgium

Full labels are given for each type specimen. Labels are rectangular and white, unless otherwise mentioned. An inventory number starting with the initials MZB (former acronym Museum of
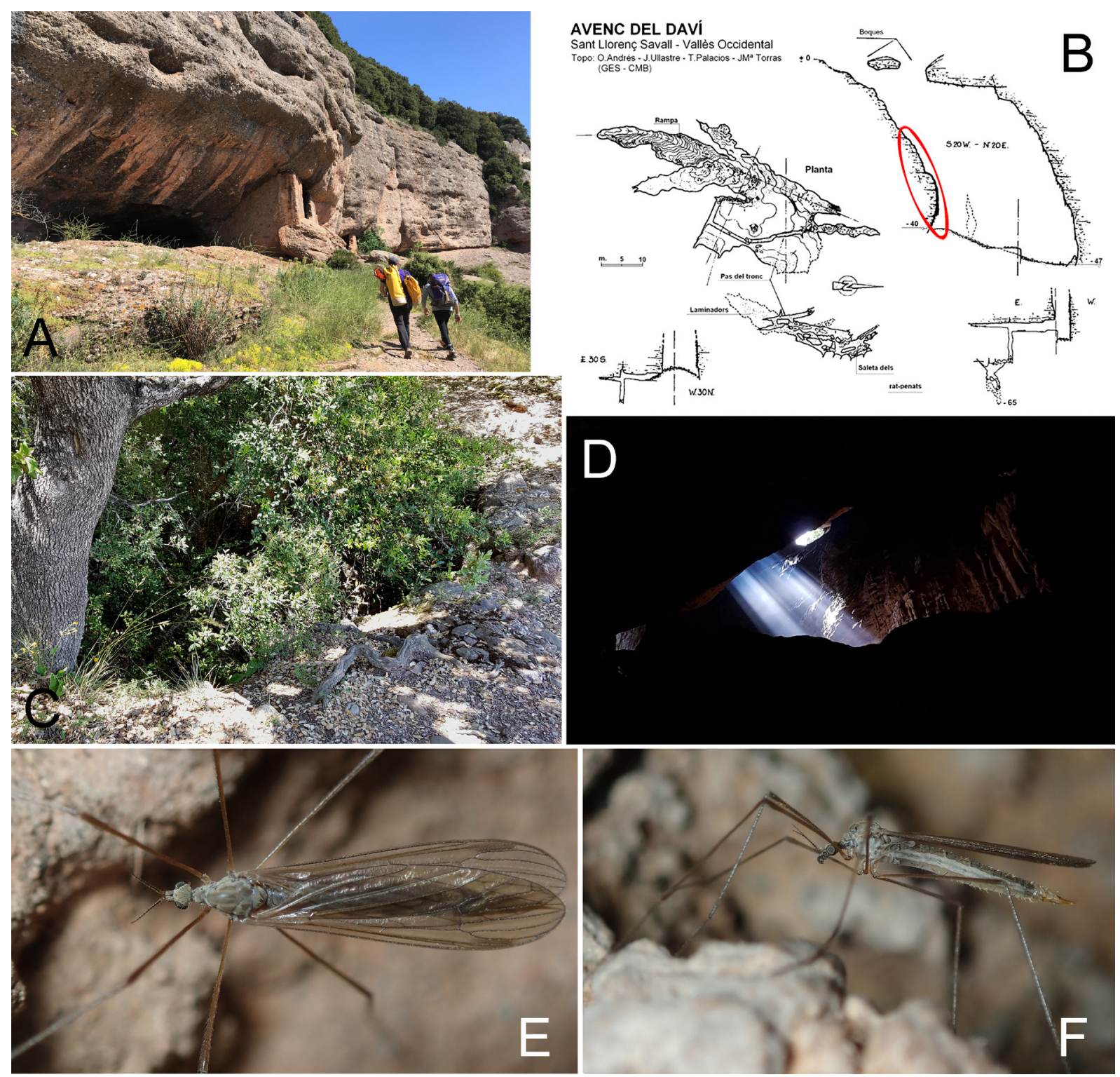

Fig. 1. A. General view of the landscape at the approach to Avenc del Daví. B. Cave topography. Indicated in red where Dicranophragma (B.) relictum Mederos sp. nov. was found. C-D. Cave entrance and view from inside. E-F. Female specimen of D. (B.) relictum Mederos sp. nov. (MZB 2019-0951, $\mathrm{MCNB}$ ) photographed in the cave (E, dorsal view; F, lateral view). 
Zoology of Barcelona) was attached to each specimen deposited in MCNB and the data were entered into the respective collection database http://zoologiaenlinia.museuciencies.cat. Likewise, an inventory number starting with the initials ED (indicating Entomology and Diptera, respectively) was attached to the specimens deposited in MNHN and data were added to the respective collection database https://science.mnhn.fr/institution/mnhn/collection/ed/item/search. Finally, an inventory number starting with the initials I.G. (Inventory General) was attached to the specimens deposited in RBINS and data were added to the DARWIN database https://darwin.naturalsciences.be/ and also on http://virtualcollections.naturalsciences.be/.

\section{Abbreviations}

\section{Wing venation}

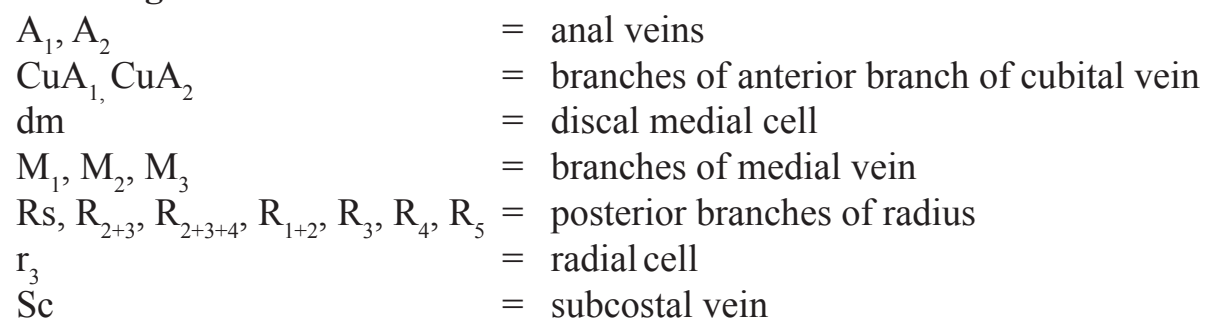

\section{Female terminalia}

iw $=$ inner wall of tergite 9

spr $=$ spermathecae

va $=$ vaginal apodeme

A total of 10 male and 16 female specimens of this new species of Dicranophragma were studied and a key is offered for the identification of the three species of this genus present in the Iberian Peninsula.

\section{Key to the species of the genus Dicranophragma known from Iberian Peninsula}

1. Wing without spots, only stigma marked, sometimes poorly defined; light brown 2

- Stigma dark, well-marked, light brown spots at origin of Rs, median vein and basal end of discal cell

D. (B.) adjunctum (Walker, 1848)

2. Stigma poorly defined, light-grey pleura, antenna reaching to about mid coxa, body length 6.0 $8.5 \mathrm{~mm}$, wing length $6.0-9.5 \mathrm{~mm}$

D. (B.) nemorale (Meigen, 1818)

- Stigma light-brown, pleura grey to greenish gray, antenna barely reaches fore coxa, body length $7.0-11.5 \mathrm{~mm}$, wing length 7.4-10.5 mm

D. (B.) relictum Mederos sp. nov.

\section{Results}

Phylum Arthropoda von Siebold, 1848

Class Insecta Linnaeus, 1758

Order Diptera Linnaeus, 1758

Family Limoniidae Rondani, 1856

Subfamily Limnophilinae Bigot, 1864

Genus Dicranophragma Osten Sacken, 1860

Dicranophragma Osten Sacken, 1860: 240 (as subgenus of Limnophila; original description). Type species: Limnophila fuscovaria Osten Sacken, 1860 (Nearctic), by monotypy. 
Subgenus Brachylimnophila Alexander, 1966

Brachylimnophila Alexander, 1966: 119 (as subgenus of Limnophila; original description). Type species: Limnophila brevifurca Osten Sacken, 1860 (Nearctic), by original designation.

Dicranophragma (Brachylimnophila) relictum Mederos sp. nov.

urn:1sid:zoobank.org:act:06E1B5A9-0618-4121-832E-094B65D3B55A

Figs $1 \mathrm{E}-\mathrm{F}, 2-3,4 \mathrm{~A}-\mathrm{D}, \mathrm{G}, 5 \mathrm{~A}-\mathrm{B}, \mathrm{D}$

\section{Differential diagnosis}

General coloration grey to greenish grey, greenish grey hue on thorax in some specimens; dark grey on abdomen. Wings yellowish-brown, veins brown, a little more than four times as long as wide, stigma light brown, poorly defined in some specimens. Petiole of $\mathrm{M}_{1}$ and $\mathrm{M}_{2} 2.5-3$ times as long as these veins. Male terminalia in lateral view with acute distal upper part of aedeagus, longer than the lower part. Female terminalia with three spermathecae. Body length 7.0-11.5 mm, wing length 7.4-10.5 mm. The morphologically closest species is $D$. nemorale (Figs 4E, H, 5E). These two species can be separated by the bi-colored appearance of $D$. nemorale (light-grey thorax and pale-brown abdomen) compared to the more uniform grey to greenish grey coloration of $D$. relictum Mederos sp. nov., by the color of the legs (completely yellow in $D$. nemorale in contrast to the progressively darker brown towards tarsi in $D$. relictum Mederos sp. nov.), and by the shape of the aedeagus in male terminalia (Fig. 4), in both lateral and dorsal views.

\section{Etymology}

The new specific name is a qualifying adjective and a term that comes from the Latin word 'relictum' that refers to the isolated situation of this species.

\section{Material examined}

\section{Holotype}

SPAIN - Ō; Catalonia, Barcelona, Sant Llorenç Savall, Parc Natural Sant Llorenç del Munt i l'Obac, Avenc del Daví; 932 m a.s.1.; 25 Jul. 2019; J. Mederos, S. Gago, F. Fadrique and X. Oller leg.; specimen collected at $-40 \mathrm{~m}$ depth; dry specimen, pinned with minute pin on foam; MZB 2019-0985.

\section{Paratypes}

SPAIN • 1 Õ, 2 क $о$; same collection data as for holotype; dry specimens; MZB 2019-0986 to 2019$0988 \bullet 1$ 万人, 2 우; same collection data as for holotype; J. Mederos leg.; specimens collected at $-20 \mathrm{~m}$

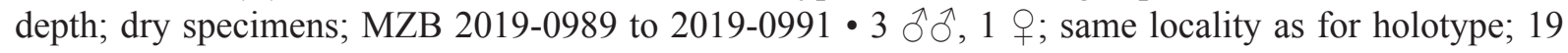
Jun. 2019; J. Mederos, S. Gago and F. Fadrique leg.; specimens collected at $-40 \mathrm{~m}$ depth; dry specimens; MZB 2019-0944 to 2019-0947 • 1 万, 2 우; same locality as for holotype; 19 Jun. 2019; J. Mederos, S. Gago and F. Fadrique leg., specimens collected at $-40 \mathrm{~m}$ depth; in ethanol 70\%; MZB 2019-0949 to 2019-0951 • 1 J, 1 o ; same locality as for holotype; 19 Jun. 2019; J. Mederos leg.; specimens collected between -7 to -27 m depth; in ethanol 70\%; RBINS I.G. $34107 \bullet 1$ o, 1 \%; same locality as for holotype; 19 Jun. 2019; J. Mederos leg.; specimens collected between -7 to $-27 \mathrm{~m}$ depth; in ethanol $70 \%$; MNHN ED10669, ED10670 • 5 ㅇ; ; same locality as for holotype; 19 Jun. 2019; J. Mederos leg.; specimens collected between -7 to -27 m depth; in ethanol 70\%; MZB 2019-0954, MZB 2019-0955, MZB 20190980 .

\section{Other material examined}

SPAIN • 1 O , 2 q $q$; same collection data as for holotype; in absolute ethanol; MZB 2019-0992 to 20190994. 


\section{Description}

\section{Male}

MeAsurements. Body length (without antennae) 7.0-7.2 mm. Antenna length 1.3-1.5 mm. Wing length 7.4-8.0 mm.

HEAD (Fig. 2). Grey pruinosity, some specimens with small dark grey dots; small concavity (depression) on vertex, which seems darker in contrast to the surrounding area due to reflection of light. Antenna
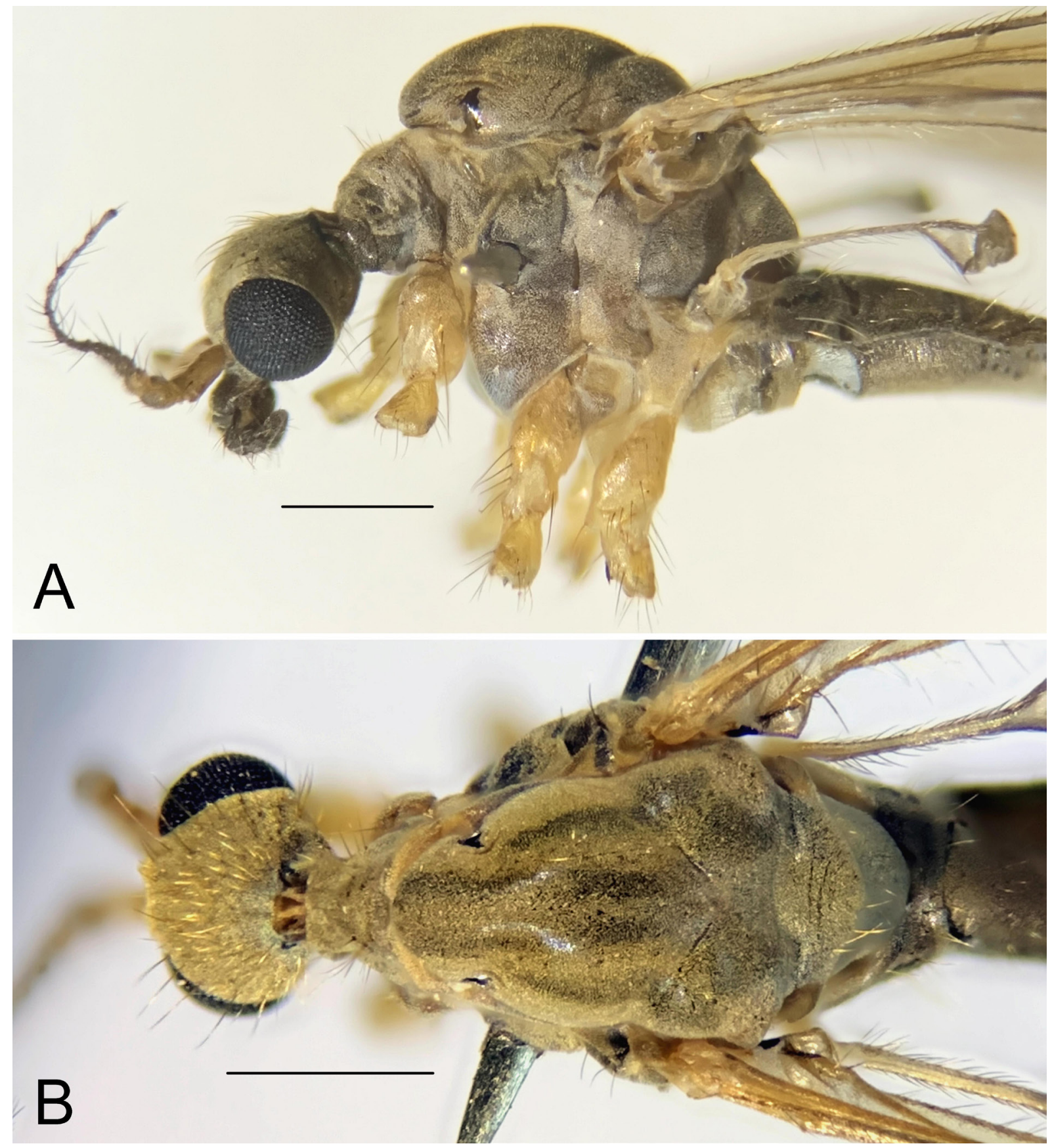

Fig. 2. Dicranophragma (B.) relictum Mederos sp. nov., holotype, ડ̊ (MZB 2019-0985, MNCB). Head and thorax. A. Lateral view. B. Dorsal view. Scale bars $=0.5 \mathrm{~mm}$. 
barely reach fore coxa; scape and pedicel yellow to yellowish brown, pedicel brown in distal half; first flagellomere yellow to yellowish brown, other flagellomeres brown to dark brown towards tip; terminal flagellomere longer than penultimate one; flagellomeres ovoid, narrower and shorter towards tip; verticils about 1.5-2 times as long as their respective flagellomeres.

Thorax (Fig. 2). Grey to greenish grey, occasionally with some brown hues; some specimens have small, dark grey to black dots scattered overall; prescutum with four, dark grey to brownish grey longitudinal stripes, two long central stripes and two other short lateral stripes; in some specimens, the two longitudinal central stripes merge into one broad stripe. Pleura light grey to greenish grey. Coxae and trochanters yellow to yellowish brown. Legs yellowish brown, progressively browner towards tarsi.

WING (Fig. 3). Tinged pale brown to yellowish brown, just over four times as long as wide, veins brown to dark brown, stigma light brown and in some specimens poorly defined. Venation: $\mathrm{R}_{2+3}$ of variable length, from just longer than $R_{2+3+4}$ to more than twice as long; petiole of $M_{1}$ and $M_{2}$ between 2.5-3 times as long as these veins but in some specimens up to six times this length due to reduction of cell $\mathrm{m} 1$ (Fig. $3 \mathrm{H}$ ); cell dm hexagonal, with some variability in shape and length.

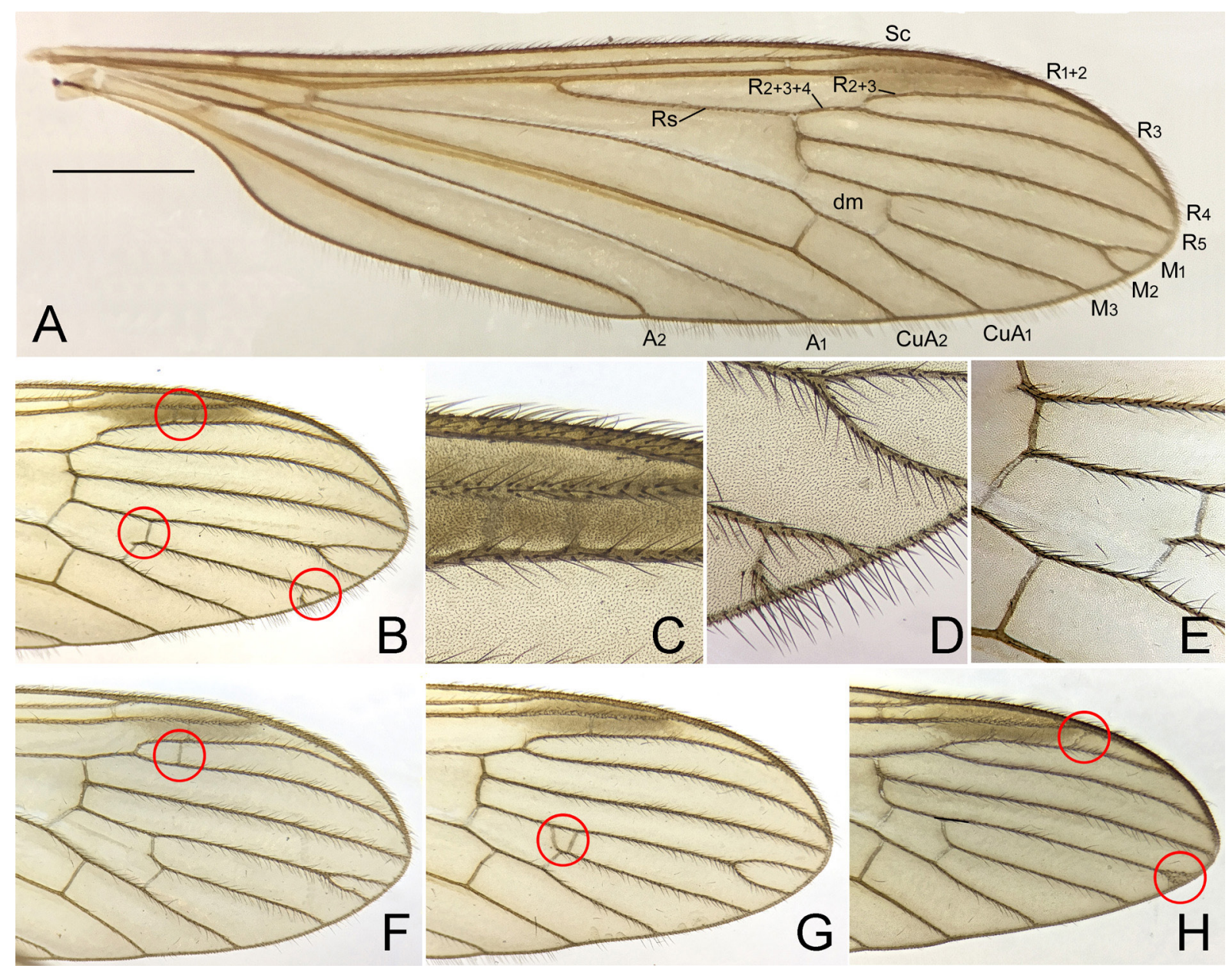

Fig. 3. Dicranophragma (B.) relictum Mederos sp. nov. A. Wing venation. B-H. Variations detected in some specimens such as extra cross veins $(\mathrm{C}, \mathrm{F}-\mathrm{H})$ and the split at the end of $\mathrm{M}_{3}$ vein creating a cell (D), as well as variations in the length and shape of cell $\mathrm{dm}$ and cell $\mathrm{ml}(\mathrm{B}, \mathrm{F}-\mathrm{H})$. Scale bar $=1.0 \mathrm{~mm}$. 
AвDOMEn. Grey to greyish brown, covered with short fine silver hairs; apical edge of tergite 7 and tergite 8 dark grey to brown, together with corresponding sternites; tergite 9 yellowish brown, terminalia yellow.

Male terminalia (Fig. 4A-D, G). Gonocoxite conical, less than twice as long as outer gonostylus; outer gonostylus stouter, moderately arched on apical half, paler in two proximal thirds and darker in distal third, with bi-toothed apex. Inner gonostylus fleshy, conical, shorter than outer gonostylus, slightly
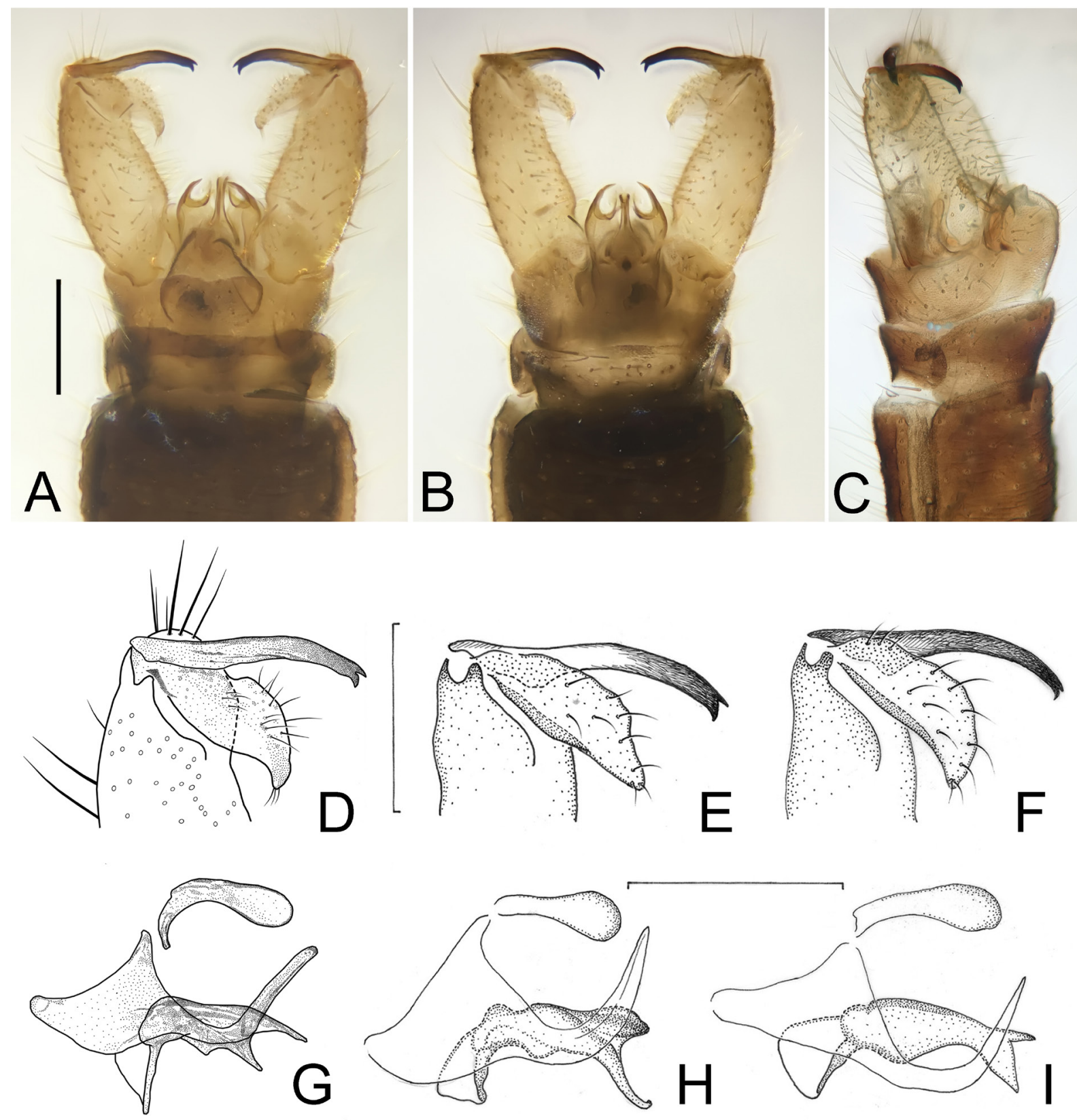

Fig. 4. A-C. Male terminalia of Dicranophragma (B.) relictum Mederos sp. nov. A. Dorsal view. B. Ventral view. C. Lateral view. D-I. Detail of inner and outer gonostylus (dorsal view) and aedeagal complex (lateral view). D, G. D. (B.) relictum Mederos sp. nov. E, H. D. (B.) nemorale (Meigen, 1818). F, I. D. (B.) adjunctum (Walker, 1848). Scale bars $=0.25 \mathrm{~mm}$ (images E-F, H-I after Starý \& Reusch 2009). 
curved at apex and with several hairs at tip; interbase spoon-like; paramere moderately stout, long and obtuse at apex; aedeagus bipartite distally in lateral view, with upper part acute and longer than lower part.

\section{Female}

Measurements. Body length 10.5-11.5 mm. Antennae 1.6-1.8 mm. Wing length 9.7-10.5 mm.

As male in general aspect and color, but larger in body size and wingspan. Verticils shorter, about twice as long as their respective flagellomeres. Female terminalia (Fig. 5A-B, D) with internal structures as shown in Fig. 5D. Vaginal apodeme (genital fork) short and rather broad. Another prominent feature to consider, in addition to the shape of the vaginal apodeme, is the significant reduction of the inner walls of tergite 9 in the internal structure of the terminalia compared to those of the other species present in the Iberian Peninsula. Spermathecae dark brown, ovoid, the length of the sclerotized parts of their ducts about 2 times as long as the spermatheca (Fig. 5D).

\section{Biology}

The specimens of D. relictum Mederos sp. nov. reacted little to human contact, either when we were taking photographs just a few centimeters away or when captured. No flight reactions were observed in any specimen of either sex, they only walked on the walls of the chamber or substrate when moving away from their initial resting sites. Only once was a slight wing fluttering observed but without taking flight. An analogous behavior was observed in specimens of the cranefly Tricyphona (Tricyphona) contraria Bergroth, 1888 in another cave with a similar speleogenesis, also in conglomerates and of similar age, in the Montserrat massif, approximately $20 \mathrm{~km}$ from Avenc del Daví (Mederos et al. 2018). The temperature and relative humidity during the study period oscillated between $7.2-9.3^{\circ} \mathrm{C}$ and $89.3-$ $91.8 \% \mathrm{RH}$. Venation in craneflies is prone to individual anomalies, including the addition of cross veins and the opening of cells due to vein atrophy (Edwards 1938; Gelhaus 2009), and we found anomalies in several specimens of this population of $D$. relictum Mederos sp. nov.

Larvae of Dicranophragma have been reported to be semi-aquatic, being found in springs and beds of fine-grained sediments in large water courses, in marginal situations along flowing and standing waters, in the more or less saturated organic mud of lake margins and marshes, and in rich organic mud near reservoirs (Reusch \& Schrankel 2006; Kramer \& Withers 2007; Podenas \& Podeniene 2008; Cranston \& Drake 2010). Adults have been observed and collected from a variety of habitats including wet mineral and peaty soils, especially wet meadows, small swampy wooded areas, wet scrapes in a field, marshland, a forest above riverbanks, emerging from a forest floor in a beech (Fagus sp.) forest; with a preference for mildly calcareous soils within wet wooded habitats, and in a semi-wet Fraxinus forest (Crossley 2003; Boardman 2007, 2016; Nielsen \& Nielsen 2009; Starý \& Reusch 2009; Drake 2011; Chandler 2015). The absence of the aforementioned ecological conditions in the massif, particularly in the vicinity of the cave, suggests that $D$. relictum Mederos sp. nov. is isolated in Avenc del Daví and a remnant of a time when the species was found elsewhere in the region when it was characterized by different conditions.

The population of $D$. relictum Mederos sp. nov. in Avenc del Daví is located approximately from a depth of $-7 \mathrm{~m}$ to the chamber located at approximately $-40 \mathrm{~m}$. Several other species of arthropods were observed and sampled in this area, including Limonia nubeculosa Meigen, 1804 (Diptera: Limoniidae), the only other cranefly observed in this cave and very abundant during the prospecting dates (June-July 2019). The specimens of L. nubeculosa were distributed uniformly over the walls of the cave, while D. relictum Mederos sp. nov. was found only in specific spaces on the west wall (descent ramp) and on the floor of the chamber located at $-40 \mathrm{~m}$. 

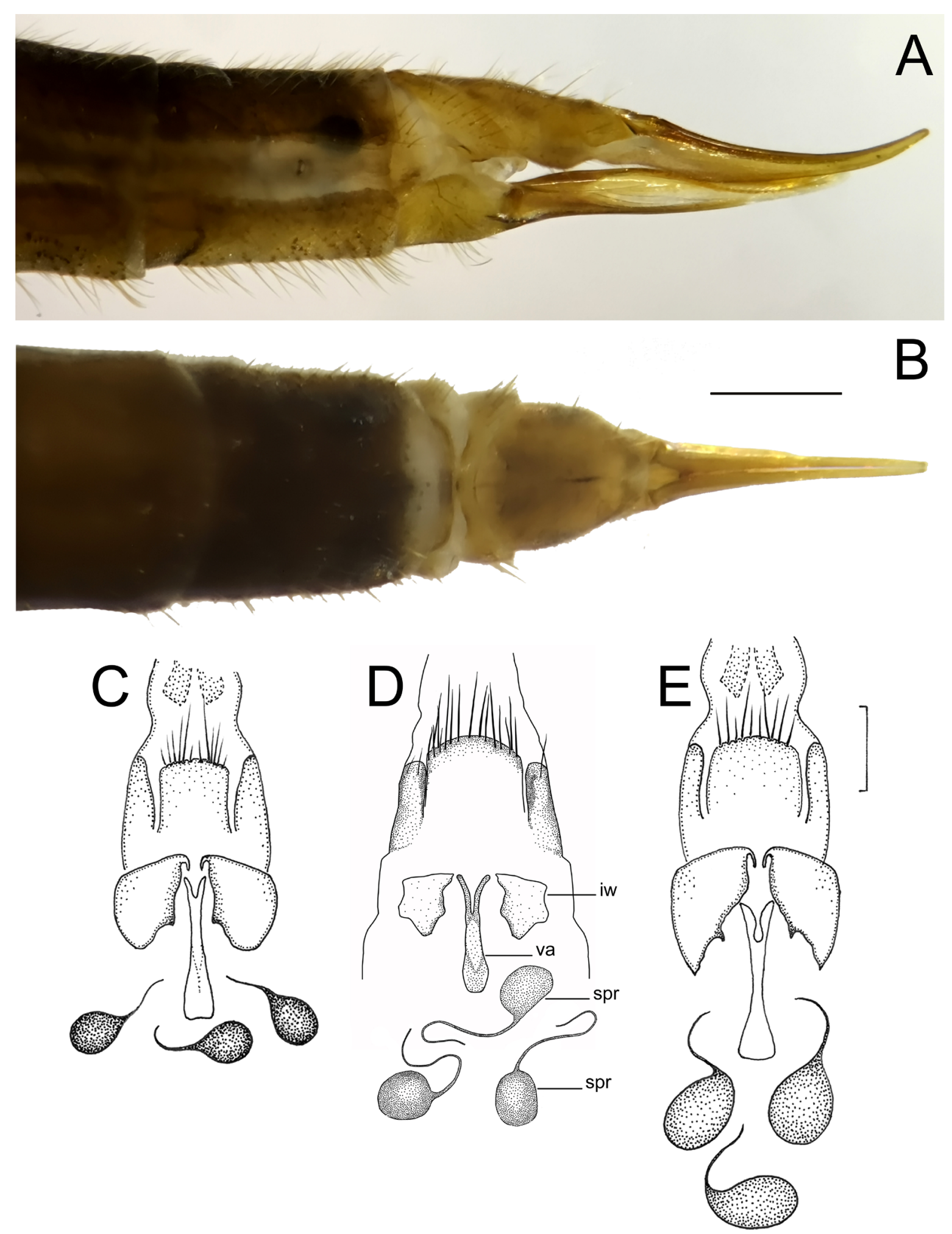

Fig. 5. A-B. Female terminalia of Dicranophragma (B.) relictum Mederos sp. nov. A. Lateral view. B. Dorsal view. C-E. Comparison of the internal structures of female terminalia of three Dicranophragma species (ventral view). C. D. (B.) adjuntum (Walker, 1848). D. D. (B.) relictum Mederos sp. nov. E. D. (B.) nemorale (Meigen, 1818). Abbreviations: see Material and methods. Scale bars $=0.25 \mathrm{~mm}$ (images C and E after Starý \& Reusch 2009). 


\section{Distribution}

Species known only from the type locality, Avenc del Daví cave in Catalonia.

\section{Remarks}

The examination of the specimens captured in Avenc del Daví reveals differences in structure, both in male terminalia as well as the spermathecae and shape of the inner wall of tergite 9 in female terminalia, that are constant and sufficient to regard this as a distinct from other European species of Dicranophragma. Dicranophragma relictum Mederos sp. nov. can also be distinguished by external characters, such as the body coloration, wing venation and wing pattern. The closest species is $D$. nemorale, as shown in the differential diagnosis section, widely distributed in the Palearctic and cited in the Iberian Peninsula from Andorra, Portugal and more recently from Spain (Eiroa 2002; Hancock 2020; Hancock \& Hewitt 2020; Oosterbroek 2020).

\section{Discussion}

During the study, Dicranophragma relictum Mederos sp. nov. was not observed in any of the other caves in the Sant Llorenç del Munt i Serra de l'Obac Natural Park. Despite the presence of caves with a similar speleogenesis, altitude, development and age, no other cave visited during the study offered similar conditions of humidity, temperature and orientation.

In Europe, there are no records of species of this genus from caves (Oosterbroek 2020) and so we believe that $D$. relictum Mederos sp. nov. could be a eutroglophile species lacking a population outside the cave. According to Sket (2008), a eutroglophile is an aboveground species that is also able to maintain a permanent underground population. It is possible that life conditions changed drastically for $D$. relictum Mederos sp. nov. when the ecological parameters that allowed the survival of the population outside the cave were modified by some specific historical event.

Dicranophragma relictum Mederos sp. nov. is a very interesting species that joins the few European members of this genus. Presumably, the population in Avenc del Daví is a remnant of an era when conditions were more appropriate for its survival in the territory, different from those of today. This population seems to be isolated in the Avenc del Daví, which offers a suitable substrate and more or less stable humidity and temperatures that are more favorable than the conditions outside the cave. A more exhaustive exploration of caves with appropriate conditions for D. relictum Mederos sp. nov., as well as in nearby outdoor environments, is still pending. This new discovery obliges the administration of this natural park to review the current access protocol to this cave, given the likelihood that $D$. relictum Mederos sp. nov. is a vulnerable and endangered species, with a single known population and dependent on an ecosystem as fragile and threatened as the hypogeum environment.

\section{Acknowledgments}

Jaroslav Starý (Silesian Museum), Eulalia Eiroa (University of Santiago de Compostela), and Boris Sket (University of Ljubljana) are thanked for their valuable comments and support. Thanks to Xavier Oller (Espeleo Club Sabadell) for assistance in the field. We are grateful to Jordi Serra-Cobo (IRBio, University of Barcelona), Wouter Dekoninck (RBINS), Christophe Daugeron and Emmanuel Delfosse (MNHN) for their help and facilities provided during the preparation of the manuscript. We also thank Mike Lockwood for the English revision. We feel grateful to Daniel Pons Julià (DIBA, Barcelona) and the park staff who provided support during the study. We acknowledge financial support through the agreement signed between the Barcelona Provincial Council (DIBA), the Barcelona Natural Science Museum (MCNB), the Catalan Biospeleological Association (BIOSP), and the Catalan Speleological Federation (FCE), to promote collaboration in research projects in karst environments and in the heritage of collections belonging to the network of Natural Parks run by DIBA. This paper is the result of the 
study Artròpodes del medi hipogeu del Parc Natural de Sant Llorenç del Munt i l'Obac 2019. The authors also thank the observations offered by two anonymous referees, which have improved the final quality of the manuscript.

\section{References}

Alexander C.P. 1966. New subgenera and species of crane-flies from California (Ptychopteridae and Tipulidae: Diptera). Transactions of the American Entomological Society 92: 103-132.

Boardman P. 2007. A Provisional Account and Atlas of the Craneflies of Shropshire. Privately published, Oswestry.

Boardman P. 2016. Shropshire Craneflies. Field Studies Council, Telford.

Chandler P.J. 2015. Diptera recorded at Bushy Park, Middlesex. Dipterists Digest ( $2^{\text {nd }}$ series) 22: 69-110.

Colombi D., Serra-Cobo J., Métras R., Apolloni A., Poletto C., López-Roig M., Bourhy H. \& Colizza V. 2019. Mechanisms for lyssavirus persistence in non-synanthropic bats in Europe: insights from a modeling study. Scientific Reports 9 (1): 537. https://doi.org/10.1038/s41598-018-36485-y

Cranston P. \& Drake C.M. 2010. Immature stages of flies and some microhabitats: water. In: Chandler P.J. (ed.) A Dipterists Handbook, $2^{\text {nd }}$ Ed: 170-176. The Amateur Entomologist 15, The Amateur Entomologist Society. London.

Crossley R. 2003. Entomological report: Diptera (Tipuloidea and Empidoidea). Naturalist (Sheffield) 128: 59-64.

Cumming J.M. \& Wood D.M. 2009. Adult morphology and terminology. In: Brown B.V., Borkent A., Cumming J.M., Wood D.M., Woodley N.E. \& Zumbado M.A. (eds) Manual of Central American Diptera. Vol. 1: 9-50. NRC Research Press, Ottawa.

DIBA. 2020. Parcs de Catalunya, Xarxa de Parcs Naturals. Diputació de Barcelona. Available from https://parcs.diba.cat/web/santllorenc/flora-i-vegetacio [accessed Mar. 2020].

Drake C.M. 2011. The Diptera of a wet woodland in Devon. Dipterists Digest (2 $2^{\text {nd }}$ series) 18: 9-26.

Edwards F.W. 1938. British short-palped craneflies. Taxonomy of adults. Transactions of the Society for British Entomology 5: 1-168.

Eiroa E. \& Báez M. 2002. Limoniidae. In: Carles-Tolrá Hjorth-Andersen M. (coord.) Catálogo de los Diptera de España, Portugal y Andorra (Insecta). Monografías de la Sociedad Entomológica Aragonesa 8: $54-57$.

Gelhaus J.K. 2009. Tipulidae (crane flies, Tipúlidos). In: Brown B.V., Borkent A., Cumming J.M., Wood D.M., Woodley N.E. \& Zumbado M.A. (eds) Manual of Central American Diptera. Vol. 1: 193-236. NRC Research Press, Ottawa.

Hancock E.G. 2020. Some cranefly records from Cazorla National Park, Jaen Province, Spain with description of a new species of Baeoura (Diptera, Tipuloidea). Dipterists Digest (2 ${ }^{\text {nd }}$ series) 27: 91-100.

Hancock E.G. \& Hewitt S.M. 2020. Craneflies (Diptera, Tipuloidea) trapped by the leaves of longleaved Spanish butterwort, Pinguicula vallisneriifolia Webb (Lentibulariaceae). Dipterists Digest (2 ${ }^{\text {nd }}$ series) 27: 45-49.

Kramer J. \& Withers P. 2007. Craneflies (Diptera) from the Pierre Verots Nature Reserve, St Jean de Thurigneux, Ain, France. Dipterists Digest ( $2^{\text {nd }}$ series) 13: 157-163.

Mederos J., Gago S. \& Eiroa E. 2018. Primera cita de Tricyphona (Tricyphona) contraria Bergroth, 1888 (Diptera: Pediciidae) para la Península Ibérica y otros registros interesantes de Tipuloidea capturados en 
cuevas de Cataluña (España). Butlletí de la Institució Catalana d'Història Natural 82: 89-96. Available from https://www.raco.cat/index.php/ButlletiICHN/article/view/101990 [accessed 5 Nov. 2020].

Nielsen B.O. \& Nielsen L.B. 2009. Emergence of soil nematocerans (Diptera, Nematocera) in a beech stand. Entomologiske Meddelelser 77: 117-135. [In Danish with English summary.]

Oosterbroek P. 2020. Catalogue of the Craneflies of the World (CCW). Available from http://ccw.naturalis.n1/ [accessed Feb. 2020].

Osten Sacken C.R. 1860. New genera and species of North American Tipulidae with short palpi, with an attempt at a new classification of the tribe. Proceedings of the Academy of Natural Sciences of Philadelphia 1859: 197-254. Available from https://www.biodiversitylibrary.org/part/26276\#/summary [accessed 23 Nov. 2020].

Podenas S. \& Podeniene V. 2008. Tipuloidea excl. Tipulidae. In: Ziegler J. (ed.) Diptera Stelviana. Vol. 1. Studia Dipterologica Supplement 16: 345-354.

Reusch H. \& Schrankel I. 2006. 6.13.1 Schnakenartige (Tipulomorpha). In: Gerecke R. \& Franz H. (eds) Quellen im Nationalpark Berchtesgaden. Lebensgemeinschaften als Indikator des Klimawandels. Forschungsbericht Nationalpark Berchtesgaden 51: 177-182.

Serra-CoboJ., Sanz-Trullén V. \& Martínez-Rica J.P. 1998. Migratory movements of Miniopterus schreibersii in the north-east of Spain. Acta Theriologica 43 (3): 271-283. https://doi.org/10.4098/AT.arch.98-22

Sket B. 2008. Can we agree on an ecological classification of subterranean animals? Journal of Natural History 42 (21-22): 1549-1563. https://doi.org/10.1080/00222930801995762

Starý J. 1992. Phylogeny and classification of Tipulomorpha, with special emphasis on the family Limoniidae. Acta Zoologica Cracoviensia 35: 11-36.

Starý J. \& Reusch H. 2009. European species of the subgenus Brachylimnophila (Diptera: Limoniidae). Entomologica Fennica 19: 207-217. https://doi.org/10.33338/ef.84437

Manuscript received: 18 June 2020

Manuscript accepted: 21 September 2020

Published on: 25 November 2020

Topic editor: Nesrine Akkari

Desk editor: Pepe Fernández

Printed versions of all papers are also deposited in the libraries of the institutes that are members of the EJT consortium: Muséum national d'histoire naturelle, Paris, France; Meise Botanic Garden, Belgium; Royal Museum for Central Africa, Tervuren, Belgium; Royal Belgian Institute of Natural Sciences, Brussels, Belgium; Natural History Museum of Denmark, Copenhagen, Denmark; Naturalis Biodiversity Center, Leiden, the Netherlands; Museo Nacional de Ciencias Naturales-CSIC, Madrid, Spain; Real Jardín Botánico de Madrid CSIC, Spain; Zoological Research Museum Alexander Koenig, Bonn, Germany; National Museum, Prague, Czech Republic. 